\title{
The Implementation of Business Judgment Rule Principle in Managing the Company
}

\author{
Busyra Azheri ${ }^{*}$, Upita Anggunsuri² \\ 12 Faculty of Law Universitas Andalas, Padang, 25163, Indonesia \\ * Corresponding author's e-mail : busyra@law.unand.ac.id
}

\begin{tabular}{|c|c|}
\hline ArTICLE INFO & Abstract \\
\hline $\begin{array}{l}\text { Keywords: } \\
\text { Bank; Board of Directors; Business } \\
\text { Judgment Rule Principle; Good } \\
\text { Corporate Governance. } \\
\text { How To Cite: } \\
\text { Azheri, B., \& Anggunsuri, U. (2020). } \\
\text { The Implementation of Business } \\
\text { Judgment Rule Principle in Managing } \\
\text { the Company. Nagari Law Review, 3(2), } \\
\text { 32-44. } \\
\text { DOI: } \\
\text { 10.25077/nalrev.v.3.i.2.p.32-44.2020 }\end{array}$ & $\begin{array}{l}\text { A business decision is very important to determine the quality of the Board of } \\
\text { Directors in carrying out their duties professionally and responsibly as expected } \\
\text { by Good Corporate Governance (GCG). The effectiveness of the Board of Directors } \\
\text { is the center of the implementation of Good Corporate Governance. Bank Business } \\
\text { is very risky (such: credit risk, reputation risk, etc.). The Board of Directors in } \\
\text { making a business decision, will always face unpredictable condition. In Banking } \\
\text { practice, the Head of Branch Office Bank is the extension of Director, if the Head } \\
\text { of Branch Office Bank signs credit agreement out of the rules (plafond). His action } \\
\text { has categorized as ultra vires, so the consequence is the Head of Branch Office Bank } \\
\text { can be held responsible for his action. In this case, the Board of Directors has not } \\
\text { taken responsibility for the action of the Head of Branch Bank, based on Business } \\
\text { Judgment Principle, the Director has not taken its responsibility for ultra vires act } \\
\text { which is done by the Head of Branch Office Bank, as along as Director has managed } \\
\text { the Company in good faith, carefully and does not against the law. Therefore, } \\
\text { Business Judgment Principle gives legal protection to the Director in making a } \\
\text { business decision. }\end{array}$ \\
\hline & (C2020 NALREV. Faculty of Law Universitas Andalas \\
\hline
\end{tabular}

\section{Introduction}

Limited Liability Company is an important business entity that the most chosen by people (entrepreneur), including Indonesia. The existence of Limited Liability Company as one of the business vehicles gives contribution to almost all part of human life. Limited Liability Company has created job vacancies, improved society welfare, and given a big contribution to economic and social development. ${ }^{1}$ In globalization and the free market era, the countries are required to implement a system and new paradigm in managing business, it is called as business activities based on corporate governance principles or well known as the Good Corporate Governance. ${ }^{2}$

The awareness of the importance of implementation Good Corporate Governance related to Bankruptcy of Enron and WorldCom business Company in the United States affect other countries to pay a big

1 Indra dan Ivan Yustiavandana. 2008. Penerapan Good Corporate Governance: Mengesampingkan Hak-Hak Istimewa Demi Kelangsungan Usaha, Jakarta: Kencana Prenada Media Grup, p. 149

2 Joni Emirzon. 2007. Prinsip-Prinsip Good Corporate Governance: Paradigma Baru Dalam Praktek Bisnis, Yogyakarta: Genta Press, p. 4. 
attention to managing the Company. The investor is surprised to see the reality of a big company in the superpower country, which is worth hundreds of billions of dollars, declared bankruptcy, just after the appearance of financial scandal which involved top executives of the Company. Enron and WorldCom's scandal, followed by scandals of several other companies such as Tyco, Adelphia. This fact gives valuable lesson that the effectiveness of the Board of Directors, is the center of the formation of Good Corporate Governance. The existence of the Board of Directors become central who has a function to improve or destroy the company he leads. However, a strict reform and supervision of the Board of Directors will create restriction to the Board of Directors in working and creating profit for the company. ${ }^{3}$ Therefore, GCG's principle must be supported by reforming and restructuring sustainable policies in the Corporate Law of the state. ${ }^{4}$

A director is the organ of the executive power holder in the Company. Director controls the daily management of the Company based on the rule, statutes, and general shareholders meeting and supervision of the Board of Commissioners. The duty and the main function of the Director are running the company's management comprehensively. ${ }^{5}$ Nevertheless, each member of Board of Directors must have a good character, experienced, qualified, and carry out activities only for the company's best interest.

Sometimes, the Board of Directors is not transparent to run its duty and authority. This condition had seen when Indonesia faced a monetary and economic crisis in 1997, which is caused big companies became collapse due to bad management. For example, in Banking, the taking over of the using of funds for long term investment but the fund used for short term activities, the violation of Legal, Lending, Limit $(3 \mathrm{~L})$, etc. ${ }^{6}$

Seeing the global dynamic currently is published, some regulations refer to GCG's focus group discussion, which has imposed on complicated duty to Director. Therefore, Director must make business decisions based on GCG's principle professionally. ${ }^{7}$ The effectiveness of Good Corporate Governance creates a system that can maintain the balance of control the company, so it can minimize opportunities for corruption, abuse of authority of each organ of the company, create an incentive for management to maximize the asset productivity and other resources so that it will had given maximum results. ${ }^{8}$

On the other hand, in running Company, Director often takes a speculative business decisions and tends to suffer losses, it can happen because a crucial condition that must be taken to save the company from greater losses or can get big profits for the company if taken actions quick right, somehow the Director's decision must be respected by all parties, because it understands about it business. ${ }^{9}$

3 Robert Prayonko,2015. Doktrin Business Judgement Rule (Aplikasinya Dalam Hukum Perusahaan Modern), Yogyakarta: Graha Ilmu, p. 1.

4 Wilson Arafat. 2008. How to implement GCG Effectively, Jakarta: Skyrocketing, p. 121

5 Mas Achmad Daniri. 2002. Good Corporate Governance Konsep dan Penerapannya dalam Konteks Indonesia, Jakarta: Gloria Printing, p. 129

6 M. Irsan Nasaruddin- Indah Surya. 2004. Aspek Hukum Pasar Modal Indonesia, Jakarta: Preneda Media, p. 244.

7 Robert Prayonko,Op Cit, p. 5

8 Joni Emirzon, Op Cit. p. 5

9 Munir Fuady. 2010. Doktrin-doktrin Modern dalam Corporate Law dan Eksistensinya dalam Hukum Indonesia, Bandung: Citra Aditya Bakti, p. 187 
Otherwise, there is also a Director who takes advantage personally on behalf of the Company. Therefore, the standard of responsibility of the Director is needed to be able to see the consequence of business decisions (the business decision is taken based on procedure or not). Based on that paradigm, the standard of responsibility of the Director is very important, so the Director can take the business decision responsibility.

If, this condition is re. ated to banking practices when a bank has faced by various risks (credit risk, market risk, operational risk, and reputation risk) (Article 4 PBI: 11/25/2009). ${ }^{10}$ Example: in taking credit decision can be made sure that credit decision has risk non-performing loan (NPL). This risk is inclusive because of many factors (internal and external). Therefore, there must be mitigation of risk to give credit and the provision about the limit of authority and responsibility to give credit. In line with Article 1 number 9 POJK (OJK Regulation) No 55 / POJK 03/2016 on the implementation of Governance for Commercial Bank about:

"Executive Officer is the official who is responsible directly to the Director or it has significant influence on policy and / or the Bank's operation, such as: the head of division, the head of regional offices, the head of branch office, the head of functional office which the position is equal to the head of the branch office, the head of the risk management unit, the head of compliance unit and the head of internal audit unit and/or other equal officials".

Related to the consequence of the responsibility of the Director and other executive officials, in Banking practice, it has analyzed by the Business Judgment Rule principle. Theoretically, this principle (Business Judgment Rule) is self-defense for the Director in managing the Company. Business Judgment Rule principle states that the Board of Directors of a company will not be liable for any loss arising from an act of decision making if the Directors act in good faith, carefully, and the best interest for the company. ${ }^{11}$

In Law Number 40 of 2007 on Limited Liability Companies has given legal protection for the Director of the Limited Liability Company, which has adopted the principle of Business Judgment Rule. The principle of the Business Judgment Rule protects the director if the Director can prove that the loss suffered by the company if not their fault or negligence. In Banking practices, the head of Branch as the extension of Director has not separated from the taking of business decisions, such as taking credit decision in a certain amount that will be responsible to the Director.

However, UUPT (Law No. 40 of 2007 on Limited Liability Companies) does not explain clearly the parameter of fault or negligence of Board of Directors or Executive Officer Company that can be taken responsibly in terms of bussines decision which can be detrimental for Company. Based on these reasons, this paper will explain about the limitations of responsibility of the Board of Directors in managing the Company and the implementation of the Business Judgment Rule Principle (Responsibility of Director Limited Liability Company) in Banking practices in achieving Good Corporate Governance (GCG).

10 Wahyudi Zarkasy. 2008. Good Corporate Governance (Pada Badan Usaha Manufaktur, Perbankan dan Jasa Keuangan Lainnya), Jakarta: Alfabeta, p. 111

11 Gunawan Widjaja. 2008. Seri Pemahaman Perseroan Terbatas (150 Pertanyaan tentang Perseroan Terbatas), Jakarta: Forum Sahabat, p. 41 


\section{Analysis and Discussion}

\subsection{The limitations of Responsibility of the Board of Directors in Managing the Company}

In Article 1 point 5 of UUPT states that "Board of Directors means the company organ with full authority and responsibility for Company's management and Company's interest following the company's purposes and objectives and to represent the Company inside and outside of court under the provisions of the statute."12 Based on the definition above, the Board of Directors have two main functions; they are management and representation functions. Both functions complete each other. ${ }^{13}$

Director, as a manager, the Company, is the responsible party for the progress and deterioration of the company, especially to actualize the objectives of the Company. Manage the company, the Board of Directors must be complete by the authority to be able to act (legal action), or they must be able to act as a legal subject.

Meanwhile, the representation functions as the actualization of a legal subject that stick on Company as rechtpersoon. In this representation function, the Director who takes legal action is not in a personal capacity as an individual but as the company. ${ }^{14}$ Duties and responsibilities of management and representation which is owned by the Board of Director has based on two things: the dependence of the Company on the Board of Directors through the management and representatives of the Company and the Company as the reason for the existence of the Board of Directors, if there is no Company, there is no Board of Directors. Therefore, between the Company and the Board of Directors, there is a fiduciary relation (relationship of trust) which produces the fiduciary duties of the Board of Directors. ${ }^{15}$ Director performs the duty management based on trust, good faith, the company's best interest, and the statute.

In Article 2 of the Law No 40 of 2007 on Limited Liability Company, has limited about object, and business activities. The limitation contains "prohibition," which doesn't conflict with the provisions of legislative regulations, public order, morality. In other words, the establishment of the company has a certain objective and purpose or called by vision and mission. The mission is a statement to explain why a company has established; meanwhile, vision is a statement to answer as to whether the Company will be in a certain period. Therefore, every decision Director should be directe in line with the vision and mission, which has been determining.

The Inclusion objective, purpose, and business activities in the statute Company hold principle function and legal foundation for the management. Thus, each transaction or contract that the Board of Directors did "not deviate" or exit or "beyond" of the objective and purposes, business activities which stated in the statue. ${ }^{16}$ The main purpose of the inclusion of objectives, purpose, and business activities in the statue, among others: ${ }^{17}$

1. To protect the Shareholder as an investor in the Company. Shareholders invest capital investment or money by buying shares of the Company, have the right to know for what its money used.

12 Tri Budiyono. 2011. Hukum Perusahaan,Salatiga: Griya Media, Salatiga, p. 167

13 ibid

14 Ibid, 168

15 Munir Fuady, Op Cit, p. 31

16 Yahya Harahap. 2011. Hukum Perusahaan, Jakarta: Sinar Grafika, p. 61

$17 \mathrm{Ibid}, \mathrm{p} .62$ 
2. By knowing the objectives, purposes, and business activities, the Shareholders as investors will has assured that the management Company board of directors will not perform the contract or transaction or action that "speculative" outside of the statue.

3. The Board of Directors doesn't approve transactions that is out of its "authority" objectives and purposes and business activities, as mentioned in the statue, which is "ultra vires."

If the Board of Directors does act, out of its authority (out of objective, purpose, and business activities), it has categorized to perform ultra vires. So, the Board of Director's actions has limited by the Company's purpose (statute). The capacity of the Company does contract or transaction as well as a donation as the limited purpose, which has stated in the statute. Out of that is out of authority of the Company. It is categorized (ultra vires). ${ }^{18}$

If the members of the Board of Directors abuse their position as a holder of fiduciary of Company or if they do fault or negligence in running their duties, which caused Company getting loss so that each member of the Board of Directors is responsible individually. In line with, In Article 97, paragraph 2 of the Law No 40 of 2007 on Limited Liability Company states that the management shall a performed by each member of the board of directors in good faith and full of liability. Then, in Article 97, paragraph 3 of the Law, No. 40 of 2007 on Limited Liability Company stated that each member of the Board of Directors should be fully personally responsible for the company's losses if the Director concerned is at fault or negligence in carrying out his/her duties. It also became one of the ways for the Board of Directors can be free from personal and jointly responsible as stated in Article 97 paragraph 4 .

Meanwhile, the members of Board of Directors cannot be taken responsibility for the losses if Director can prove that in Article 97 paragraph 5:

a) The losses were not due to their fault or negligence;

b) They carried out the management in good faith and with prudence in the interests of and accordance with the purposes and objectives of the Company;

c) They don't have a direct or indirect conflict of interest in the action of management that caused the losses and;

d) They took action to prevent the losses from arising or continuing.

2.2. The Implementation of the Business Judgment Rule Principle (Responsibility of Director Limited Liability Company) in Banking practices in achieving Good Corporate Governance (GCG)

The Business Judgment Rule principle is the self-defense for the Director in managing the Company. Business Judgment Rule principle states that the Board of Directors of a company will not be responsible for any loss arising from an act of decision making if the Directors act in good faith, carefully, and the best interest for the company.

Indonesia adopts a legal standard which is used to justify a business decision. It must a taken in good faith, responsible and not for Director interest as mentioned in Article 97 (1) (2) "Board of Directors shall be responsible for management of Company, and the Management shall have performed by each

18 Ibid 
member of the Board of Directors in good faith and full liability. Then, Article 99 (1) "Members of Board of Directors don't have the authority to represent the Companies if:

a) there is a case before the courts between the Company and the member of the Board of Directors concerned; or

b) the member Board of Directors concerned has a conflict of interest with the Company.

One of the reasons that this standard is very important to reduce inefficiency court, signed by lawsuit major and minor with high cost here reduced. Those standards (business decisions must be taken in good faith, responsible, and not for Director interest), give rule as guidance for the Board of Directors in making a business decision that will has explained as follows: ${ }^{19}$

1. Business Decision in Good Faith

Good faith is an abstract concept which is known as company law. When the legal issues become difficult to solve it, so the legal expert back to the good faith concept. Good faith both is extremely difficult to prove because it comes from a soul (internal) person through his/her action. However, good faith can be seen from the action "reasonable" by a person who will convince the judge that the person has acted with good faith. Director 's action who reasonable, as follows: ${ }^{20}$

a. Directors have considered the consequence that may arise before the Director takes business decisions. Director is required to be a person who can see the advantages and disadvantages that will be acquired by the Company as a result of their business decision taken.

The basic assumption is a director of the Company who makes a business decision is assumed to act based on sufficient assumption as a consideration, which is as basic consideration of the decisions taken. The two main points can be said that the business decision of Director in good faith, namely:

1) There are considerations before the director takes a decision

2) Considerations a taken for the Company's interest not Director.

b. Business decision may not give profit for Directors.

Director's interest is the company's interest. Director has not good faith if his self-interest is given priority because that Director to take business decision must be given priority rationality supported by legal reasoning so that there is a positive relationship between rationality with good faith. It must prove in Court.

Example: The Decision of Board of Directors to buy shareholders share with special price have to give the right to the other shareholders, so their share has bought at the same price. It shows good faith of Director. This point is related to the implementation of the appraisal right of shareholders. When the Company buys shares owned by two shareholders, it means that they (two shareholders) have right their shares bought at the same price.

Besides that, Law No 40 of 2007 on Limited Liability Company (UUPT) adopts good faith principles. It can be seen in Article 92 paragraph 1, which states that the Board of Directors manages the Company for Company's interest and by the Company's purpose and objective. Therefore, Director to take

19 Robert Prayonko, Op Cit, p. 75

20 Ibid p. 76 
decision refers to 3 parameters, they are the Company's interest, by the mission of the establishment of the Company, closing the Company's vision and mission. Otherwise, if Director faces the conflict of interest so good faith principle is difficult to achieve it, as stated in Article 99 (1), members of the Board of Directors don't have the authority to represent the Companies if:

a) There is a case before the courts between the Company and member of the Board of Directors concerned; or

b) The member of the Board of Directors concerned has a conflict of interest with the Company. In such events as are contemplated to in paragraph 1, person who has the right to represent the Company are:

1) other members of the Board of Directors who don't have a conflict of interest with the company

2) the Board of Commissioners in the event that all of members the Board of Directors have a conflict of interest with the Company; or

3) other parties appointed by the General Shareholders meeting if all members of Board of Directors or Board of Commissioners have a conflict of interest with the Company.

\section{Responsible Business Decision}

According to the explanation of Article 97 (2) of Law No 40 of 2007 on Limited Liability Company (UUPT), the meaning of full responsibility is to concern "carefully" and "persistent." In managing of Company's Board of Directors cannot be separated in taking a responsible business decision for Company's interest. Taking of responsible business decision by the Board of Directors, described as follows :21

a. Company management must do carefully and diligently (the duty of due care). The Board of Directors manages of the Company must be careful (the duty of due care). Board of Directors may not be careless and negligence in managing the company. If he was careless or negligence based on the law, it means he has violated the obligation to be careful (duty care) or contrary to prudential duty.

b. Company management must do duty to be diligent and skill

In general, the obliged aspect, diligent and tenacious which is always related to skill. Therefore, a member of the Board of Directors in carrying out company management must perform his skill (reasonable skill for the post).

\section{Business Decision Which Is Not to Director's Self Interest.}

Conflict of Interest is a situation in which someone's private interest has opposed to the company's interest. In carrying out duty and obligation, the Director must prioritize the company's interests above self-interest, family, and other parties. ${ }^{22}$ The Board of Directors must avoid conflict of interest in the

21 Yahya Harahap, Op Cit, p. 378

22 Wahyudi Zarkasy, Op Cit, p. 43 
running of the Company. Board of Directors must avoid conflict of interest in the running of Company management, among others :23

a. The obligation not to use the money and property of the Company for self-interest. If this obligation is violated and resulted in losses for the company so that the Board of Directors is qualified as onrechtmatigedaad (Article 1365 of KUHPdt). The Board of Directors a charged with civil and criminal liability (Article $372 \mathrm{KUHPdt}$, Article $378 \mathrm{KUHPdt}$ ).

b. You are using the information of the Company for self-interest. This action is categorized breach of fiduciary duty.

c. Do not use the position for self-interest, such as: accepting a bribe.

d. Do not take the company's profits for self-interest. It categorized as an advantage that undisclosed by the director. Therefore, that act is a conflict of interest, and it is qualified as a breach of fiduciary duty.

Conflict of Interest appears as an issue of the Business Judgment Rule because the person who has a particular position in a company that can make it possible to abuse his position for his interest or his affiliates. Therefore, the Board of Directors must sign a contract which contains obligations to avoid Conflict of Interest included to maintain the Company's secret. This step is taken some reasons, as follows : 24

a. To assist the court in asses the standard of Conflict of Interest because internal guidelines (code of conduct) can has used as a standard for the judge to assess the Conflict of Interest involving the Board of Directors.

b. Provide certainty about the action of the Director should do when face Conflict of Interest.

c. Supporting the implementation of Good Corporate Governance which affects the Corporate Performance.

When that three reasons (good faith, responsibility, and not for personal interest) have not met, the Board of Directors shall be deemed guilty (Intentional) or (Negligence) in the running of his duty, so Director must be responsible individually. Otherwise, if an honest mistake or mistake in deciding it does not violate one of the three elements above, the director can't be taken his responsibility individually.

If this condition is related to the Banking Industry, so many things can have debated, because the Banking tends to have many problems, especially related to credit as a core business Banking. Besides, to lend credit has a potential conflict of interest, which Director or the other stakeholders trapped in a business decision that tends to have many internal and external problems. For instance: in closing the attempt of giving credit/loan in which each level of Bank Office tries to reach the target determined, so it used many ways to reach the target. Here, the potency of appearing conflict of interest, so SOP (standard operational procedure) denied. If this condition not anticipated soon, so it causes the quality of credit/loan has a potency non-performing loan (NPL). Therefore, in giving credit/loan is very

23 Yahya Harahap, Op Cit, p. 377

24 Robert Prayonko, Op Cit, p. 96 
determined by the ability of credit/loan analysis and management's policy to prevent non-performing loan (NPL) occurred, Bank needs to do credit/loan analysis by using formula $5 \mathrm{C}$ as follows :25

a. Character

Assessment of the character means the character of the customer. In this case, the customer must have good character.

b. Capacity

The capacity of prospective customers to manage their business activities and the ability to see the future prospective (the measurement of this capacity can have done by assessing the balance sheet, income statement, cash flow, etc.)

c. Capital

In this case, the Bank should research capital owned by the lender.

d. Collateral

Collateral is a guarantee for the agreement of the approval loan if the lender defaults the agreements in the future, for example, non-performing loan.

e. Condition of Economy

A bank needs to pay attention to the economic condition and business condition of the lender to minimize risks caused by economic conditions.

Beside the formula $5 \mathrm{C}$ above, the giving of credit/loan by the Bank guided two principles:

a. Fiduciary Principle

In this case, it can be said that the giving loan/credit by Bank to the customer based on trust. Bank has trust that it gives loans/credit to customers, is useful for customers, and based on an agreement.

b. Prudential Principle

Bank in running its business activities, such as: in giving loan/credit to the customer, should always be guided and implement the prudential principle. This principle among others has manifested consistently and good faith to all requirements and regulations related to giving of credit by the bank concerned.

In line with the prudential principle. This element of prudential is more technical and substantive. The obligation to act carefully and good faith require the director to take business decisions considering information material properly. The can a seen in Article 8 of Law No. 10/1998 amendment of Law No. 7/92 on Banking:

(1) In extending credit or financing based on syariah principles, commercial banks shall have confidence based on thorough analysis on the intention, capability, and ability of a Debtor Customer to repay its debt or the financing according to the agreed terms A Commercial Bank shall formulate and implement guidance on Credit and Financing based on Syariah Principles, according to regulations stipulated by Bank Indonesia.

25 Hermansyah. 2005. Hukum Perbankan Nasional Indonesia, Jakarta: Kencana Prenada Media Grup, p. 63 
Based on prudential principle, the analysis of credit application has to done objectively, and it is not affected by the parties concerned with the credit applicant/lender, so it can has supposed that the loan does not develop into a problem in the future. Therefore, Director's policy needs to consider rationality and some regulations because the Bank contributes to the stability of financial markets and the development of the national economy.

Prudential principle has an important function to take credit/loan decision. There are some things that must be considered by Director to take credit/loan decision, they are: (1) limit of the authority of credit that can be given by the Director and the head of the Bank's branch (2) requirement of giving credit (3) collection of receivable bank (4) value of the guarantee (5) the value of assets debtor and the turnover company's business (6) prospect of business in the future. ${ }^{26}$

Structurally, the decision maker of credit/loan at the highest level is Director. Also, Director is legally responsible for the decisions made by the underlying decision maker of credit. If the Board of Directors as a decision maker of credit takes the wrong decision in approving the proposed loan and it causes non-performing loan in the future. In this case, the Board of Directors has the authority to decide running the business of the Bank. ${ }^{27}$

The bank has several levels and the status of its office, such as branch office headed by the head of the Branch, which is the extension of the head of the office. The legal relationship or rechtsbetreking between the Branch Office and the head Office is the vertical. It means that the branch office must comply with all the policies issued by the head Office. The branch office is the extension of the head office, the branch office can-not do any legal action by itself, without approval of the head Office, because only Director who can act inside and outside the court, as stated by Article 98 paragraph (1) Boards of Directors shall represent Company inside and outside of the court (include the legal act to sign the Credit Agreement), is responsible Director.

In order to the freedom to run the Company's objectives could be done well by the Branch Office Bank, so the Article 103 of the Law No 40 of 2007 on Limited Liability Company (UUPT) allows the Board of Directors to give authority in writing to one or more employees of the company, in this case, the Head of Branch Office Bank or other officials which is appointed by Branch Office Bank, to sign the credit agreement as described by power of attorney. Thus, to sign a credit agreement, the Head of Branch Office Bank must have a power of attorney of the Board of Directors or the Head Office Bank. Based on that power of attorney, the head of the branch office Bank can represent the Company to sign the Credit Agreement, or any other power of attorneys related to the credit agreement.

The practice of giving authority to sign the credit agreement on Branch Office Bank does not provide automatically unlimited. It means that the authority of the head of the branch office Bank based on a power of attorney to sign the credit agreement is only allowed on a certain limit (plafond) based on the policy of the bank. If the head of branch Bank sign a credit agreement, exceed of plafond so that this action can categorized as ultra vires action. The consequence is the head of the branch Bank must be responsible for itself (personally). In this case, the Board of Directors cannot be taken responsibility for the action of the head of the branch office Bank, although it is as the extension of Director.

26 Robert Prayonko, Op Cit, p. 115

27 Hendy Herijanto. 2014. "Prinsip Keputusan Bisnis Pemberian Kredit Perbankan Dalam Hubungan Perlindungan Hukum", Padjajaran Jurnal Hukum, Vol. 1 No. 3, p. 621 
In line with the Business Judgment Rule Principle, which is the Board of Directors could not be taken responsibility for ultra vires act which is done by the head of branch office Bank, as long as he manages the company in good faith, carefully and does not against the law. Moreover, the act of this the head of branch office Bank is as the implementation of his duty that he has been delegated by the Board of Directors to the head of branch office Bank as well as become responsibility of the head of branch Bank.

In the case of non-performing loan, the Bank will need to invistigate the cause first. Besides, the effort to overcome non-performing loan, banks also consider the future prospect of the debtor. The determination of these prospects can be achieved through analysis of prospect deeply by concerning the commitment and ability of the debtor to be able to get out of the problems faced. NPL (NonPerforming Loan) saving efforts are $:^{28}$

1. Rescheduling is a legal action to change some of the requirements of credit agreement related to the repayment schedule/grace period credit, the change of installment.

2. Reconditioning is changing a half or all requirements, which is unlimited to the change of installment's schedule and or grace period credit.

3. Restructuring is a change of credit agreement such as the provision of additional credit / converting all or a half of portion credit to the company that carried out with or without rescheduling or reconditioning.

In Banking, practice tends to face many problems so Director has to be made a priority. The fiduciary duty principle and Director may not be trapped ultra vires act. Therefore, Director has to implement GCG's principle. In general, the main principle of GCG consists of: 29

a) Transparency

Transparency is the company managed transparently. By transparency, other relevant parties will be able to see and understand how and what is the reason provision is made and how the company has managed.

b) Accountability

Accountability is accountability for the implementation of the functions and duties following the authority of all organs Company.

c) Responsibility

The responsibility of the company is as part of the community to stakeholders and the environment in which the Company has located.

d) Independency

The independence is a part of deciding without intervention and pressure of other parties, which is contrary to the mechanism making decision properly and rationally.

e) Fairness

Protection of the interest of minority shareholders from fraud, trading fraud, self-dealing, or insider trading.

28 Ibid, p. 76

29 Amin Widjaja Tunggal. 2007. Corporate Governance Suatu Pengantar, Jakarta: Harvarindo, pp. 6-8 
GCG implementation needs to be based on high integrity and therefore is required the Code of Conduct which can be a reference for the company organs and employees in implementing values and business ethics, so it becomes part of company culture. The function of the Code of Conduct are:30

a) Code of conduct is an elaboration company values and business ethics in running of company, so it becomes organ company's guidance and all employees.

b) The code of conduct includes the guide about conflict of interest, giving and receiving of gifts, donations, compliance with the provision of information confidentiality, and reporting of unethical behavior. Director in managing the Company cannot be separated from business decisions are taken. A business decision is very important related to determine the quality of the Board of Directors in implementing duty professionally and responsibility as expected by GCG. Thus, in term of taking business decision (credit/loan decision) in Banking, it must obey internal credit policy Bank, provision of Bank Indonesia, regulations of Banking which obligate the Director to implement prudential principle, good faith, fiduciary duty, duty of loyalty, so Director gets legal protection in taking a business decision.

\section{Conclusion}

Director must manage the company based on good faith, the company interest, objective and purpose of the Company, as stated in the statute. In Article 2 of the Law No 40 of 2007 on Limited Liability Company, has limited about object, and business activities. The limitation contains "prohibition," which doesn't conflict with the provision of legislative regulation, public order, morality. Inclusion of objective and purpose in statute are the legal foundation for Director in managing the Company, so Director does not exceed of objective and purpose of the Company, activity business as stated in the statute as well as it becomes guidance to determine the limitation of authority Director in managing the Company.

In the running of business activity. The bank faces various risks, for instance: credit risk, market risk, operational risk, and reputation risk. In taking business decision (taking credit's/loan decision) almost every credit's decision always contain an unpredictable element of the result in the future (no guarantee of a decision taken following the expected). In Banking practices, for example: the head of the branch office Bank is the extension of the Board of Directors in carrying out its duty. The head of the branch office Bank is responsible directly to the Board of Directors. If the head of branch office Bank based on a power of attorney to sign the credit agreement, it is only allowed to sign a credit agreement with a certain amount (maximum credit limit). In this case, if the head of branch office Bank signs credit agreements out of the rules. His action can has categorized as ultra vires, so the consequence is the head of the branch office Bank can be taken responsible for his action. In this case, the Board of Directors cannot be taken responsible for the action of the head of branch Bank, based on Business Judgment Principle, the Director cannot taken its responsibility for ultra vires act which is done by the head of branch office Bank, as along as Director has managed the Company in good faith, carefully and does not against the law.

30 Wahyudin Zarkasy, Op Cit, p. 42 


\section{Reference}

Books

Amin Widjaja Tunggal. 2007. Corporate Governance Suatu Pengantar. Jakarta : harvarindo.

Gunawan Widjaja. 2008. Seri Pemahaman Perseroan Terbatas (150 Pertanyaan tentang Perseroan Terbatas). Jakarta : Forum Sahabat

Hermansyah.2005. Hukum Perbankan Nasional Indonesia. Jakarta : Kencana Prenada Media Grup.

Indra dan Ivan Yustiavandana.2008. Penerapan Good Corporate Governance: Mengesampingkan Hak-Hak Istimewa Demi Kelangsungan Usaha. Jakarta : Kencana Prenada Media Grup.

Joni Emirzon. 2007.Prinsip-Prinsip Good Corporate Governance : Paradigma Baru Dalam Praktek Bisnis. Yogyakarta: Genta Press.

Mas Achmad Daniri. 2002. Good Corporate Governance Konsep dan Penerapannya dalam Konteks Indonesia. Jakarta: Gloria Printing.

M. Irsan Nasaruddin dan Indah Surya.2004. Aspek Hukum Pasar Modal Indonesia. Jakarta: Preneda Media.

Munir Fuady.2010.Doktrin-doktrin Modern dalam Corporate Law dan Eksistensinya dalam Hukum Indonesia. Bandung :Citra Aditya Bakti.

Robert Prayonko.2015. Doktrin Bussines Judgement Rule (Aplikasinya Dalam Hukum Perusahaan Modern).Yogyakarta : Graha Ilmu.

Wahyudin Zarkasy.2008. Good Corporate Governance (Pada Badan Usaha Manufaktur, Perbankan dan Jasa Keuangan Lainnya).Bandung: Alphabeta

Wilson Arafat. 2008. How to Implement GCG Effectively. Jakarta : Skyrocketing Publisher

Yahya Harahap. 2011. Hukum Perusahaan. Jakarta : Sinar Grafika.

\section{Regulations}

Undang-Undang No 40 Tahun 2007 Tentang Perseroan Terbatas

Undang-Undang No 10 Tahun 1998 atas perubahan Undang-Undang No 7 Tahun 1992 Tentang Perbankan

Peraturan Bank Indonesia No 11/25/2009 tentang Perubahan Atas Peraturan Bank Indonesia No 5/8/2003 tentang Penerapan Manajemen Resiko Bagi Bank Umum

POJK No 55/POJK 03/2016 tentang Penerapan Tata Kelola Bagi Bank Umum

\section{Journal}

Hendy Herijanto. 2014. Prinsip Keputusan Bisnis Pemberian Kredit Perbankan Dalam Hubungan Perlindungan Hukum (Padjajaran Jurnal Hukum, Vol. 1 No. 3). 